Research article

\title{
EFFECTS OF ARONIA MELANOCARPA JUICE ON PLASMA AND LIVER PHOSPHOLIPID FATTY ACID COMPOSITION IN WISTAR RATS
}

\author{
ZEC Manja ${ }^{1}$, DEBELJAK MARTAČIĆ Jasmina ${ }^{1}$, RANKOVIĆ Slavica ${ }^{1}$, POKIMICA \\ Biljana ${ }^{1}$, TOMIĆ Mirko ${ }^{2}$ IGNJATOVIĆ Đurđica ${ }^{2}$, GLIBETIĆ Maria ${ }^{1}$, POPOVIĆ \\ Tamara $^{1 *}$
}

${ }^{1}$ Center of Research Excellence in Nutrition and Metabolism, Institute for Medical Research, University of Belgrade; 11000 Belgrade, Serbia; ${ }^{2}$ Institute for Biological Research "Siniša Stanković", University of Belgrade; 11000 Belgrade, Serbia

(Received 20 July 2016, Accepted 29 December 2016)

A nutritional placebo-controlled study was performed in Wistar rats in order to investigate the effects of 5-weeks aronia juice consumption towards fatty acid (FA) composition of phospholipids in the plasma and liver, as well as plasma glucose (Glu) and cholesterol levels. The animals were divided into 3 groups of 8 animals each, and randomized to receive either the full polyphenol dose of Aronia melanocarpa juice (AMJ), 4 times less polyphenol dose $(1 / 4-\mathrm{AMJ})$ or polyphenol-lacking placebo beverage (PLB). Each group of 8 male adult Wistar rats received the liquid ad libitum. AMJ decreased the levels of low-density lipoprotein (LDL) $(\mathrm{P}<0.05)$ vs. PLB. AMJ increased dihomo$\gamma$-linoleic acid (DGLA, 20:3n-6) $(\mathrm{P}<0.05)$ and decreased arachidonic acid content (AA, 20:4n-6) $(\mathrm{P}<0.05)$ vs. PLB in liver phospholipids. AMJ significantly increased monounsaturated fatty acids (MUFA) levels both in the liver $(\mathrm{P}<0.05)$ and plasma $(\mathrm{P}<$ 0.05). Both aronia juice doses elevated the levels of beneficial $n-3$ polyunsaturated fatty acids (PUFA) in the plasma and liver. There was a dose-dependent, significant increase $(\mathrm{P}<0.001)$ in cis-vaccenic acid $(\mathrm{VA}, 18: 1 \mathrm{n}-7)$ in phospholipids in the plasma and liver. Our results indicate favorable effects of aronia juice intake on lipid parameters in Wistar rats. These findings suggest the potential of aronia dietary intake in cardiometabolic diseases primary prevention strategies in the human population.

Key words: chokeberry, polyphenols, low-density lipoprotein, arachidonic acid, monounsaturated fatty acids

\section{INTRODUCTION}

Aronia melanocarpa (AM), a berry fruit, has been scientifically investigated for a wide array of health-promoting characteristics. The beneficial properties of AM on health are attributed to the high content of non-nutritional phytochemicals i.e. polyphenols [1,2], both flavonoid and non-flavonoid subclasses. Beneficial effects of polyphenol

\footnotetext{
*Corresponding author: e-mail: poptam@gmail.com
} 
intake have been studied thoroughly [3,4], mostly in the context of chronic disease prevention.

Fatty acids (FA) are stored at different rates in different tissues [5,6], thus potentially influencing particular tissue metabolism. The phospholipid FA composition and cholesterol content are basic determinants of the physical properties of biomembranes. They have been shown to influence a wide variety of membrane dependent functions such as membrane transport, enzyme activity and receptor function [7]. The FA profile in tissues partly reflects not only the dietary fat intake, but also the efficiency of FA metabolism in the body [8]. The liver has an important role in the synthesis and metabolism of phospholipids. Liver phospholipids are a building structure of the hepatocyte membrane, they take part both in metabolic activities and repairing after metabolic disturbances [9].

Recently, rat animal models have been exploited for the investigation of the protective effects of consumption of AM polyphenols towards the accumulation of xenobiotics in soft animal tissues [10]. However, a limited number of available studies deals with the biological effects of AM consumption regarding cardio metabolic biomarkers in rats. Existing preclinical data indicate anti-oxidative [11,12], hypotensive [13], lipidlowering [1,14] and glucose-regulating [15] effects in rats treated with AMJ. There is a limited number of studies dealing with the polyphenol-rich diet impact on lipid and FA status in rodent models [16,17]. So far, none of the studies has investigated the biological effect of polyphenols contained in AMJ towards FA tissue content in rats. In addition, none of the available animal studies investigated the dose-response biological effects of aronia juice towards the status of phospholipids FA content in tissues.

We challenged the beneficial effects of aronia juice long-term consumption in rats on phospholipid plasma and liver FA composition, as well as on some biochemical parameters. Additionally, we evaluated the dose-dependent effect of consumption of aronia juice containing different polyphenol doses.

\section{MATERIALS AND METHODS}

\section{Study design and study treatments}

The animals underwent a parallel, nutritional, placebo-controlled study. The animals were fed for 5-weeks with either one of the 3 protocols: 2 doses of aronia juice ("Nutrika", Belgrade, Serbia), and PLB. PLB was synthesized to contain the exact nutritional values as aronia juice, including sugars, minerals and vitamins, but without bioactive polyphenols (N. Kardum, unpublished data). The aronia juice treatment was applied in 2 polyphenol doses: full polyphenol dose (AMJ) and a dose with exactly the same chemical composition as AMJ but with 4 times less polyphenol content $(1 / 4-A M J)$. All of the comparisons in the study were performed between animals receiving either of 2 polyphenol doses of aronia juice versus control animals receiving the placebo. 


\section{Characterization of the intervention treatments}

Analysis of phenolic compounds in AMJ was determined using a modified FolinCiocalteu method [18]. Beverage samples were diluted in distilled water to working solutions in order for absorbencies to fit the standard calibration curve in the range of $0-600 \mu \mathrm{g} / \mathrm{ml}$ of gallic acid. Results were expressed as micrograms of gallic acid equivalents per $\mathrm{ml}$ of beverage, and data are presented as mean $\pm \mathrm{SD}$ for 3 replicates. The polyphenol content of the study interventions is presented (Table 1) and quantities of phenolic compounds in AMJ were presented by Tomić et al. [19].

Table 1. Aronia juice polyphenol content

\begin{tabular}{lcc}
\hline & \multicolumn{2}{c}{ Content $(\mathbf{m g} / \mathbf{1 0 0} \mathbf{~ m L})$} \\
\hline AMJ & $1 / 4-A M J$ & PLB \\
1177.11 & 294.28 & None \\
\hline
\end{tabular}

\section{Animals}

Male, adult, 4-months old, Wistar rats, weighing 380-440 g, provided by the vivarium of the Institute for Biological Research, Belgrade, Serbia, were used in this study. The animals were kept in groups of 4 per cage, under controlled conditions (room temperature $23-25^{\circ} \mathrm{C}, 12 \mathrm{~h}$ light-dark cycle, food and drinking liquid ad libitum). All animal procedures were in compliance with Directive 2010/63/EU on the protection of animals used for experimental and other scientific purposes, and approved by the Ethical Committee for the Use of Laboratory Animals of the Institute for Biological Research "Siniša Stanković", University of Belgrade.

The animals were randomly assigned into 3 experimental groups of 8 animals each, to receive either AMJ, $1 / 4-A M J$ or PLB, supplied with $20 \%$ mixture $(\mathrm{m} / \mathrm{m})$ of experimental beverage in tap water. Fresh drinking solutions were prepared daily. The rats were fed standard briquettes including a commercial non purified diet (Veterinarski Zavod, Subotica, Serbia), containing (w/w) 20\% protein, 40\% carbohydrates, 5\% fat, fiber $8 \%$, and an adequate amount of vitamins and minerals (ash 10\%). 1 gram represented an estimated metabolic energy of $11 \mathrm{~kJ}$ with $17.09 \%$ derived from fat. The FA composition of the supplied standard briquettes was: $18.91 \%$ SFA, 29.24\% MUFA and $52.9 \%$ PUFA.

Experimental drinking solutions were offered ad libitum for 35 days. The body mass of the rats was registered on days: $-1,7,14,21,28$ and 35, and presented as mean value \pm SEM for each experimental group on the experiment weeks: 0-5 (Figure 1a). There was no statistical difference between body mass of animals between the different treatment groups on day -1 and before sacrifice on day 35 ( $\mathrm{P}>0.05$ for both measurements, data not shown). Daily consumption of drinking solutions was estimated for each group, and their average weekly consumption in $\mathrm{ml}$ of solution per 
animal/day are presented in Figure 1b. Food consumption per cage was estimated 3 times a week and described as $\mathrm{g}$ of food/animal/day of every week of the experiment (Figure 1c). According to the determined polyphenol content, we have calculated the daily average intake of polyphenols to be 557.22 and $120.64 \mathrm{mg}$ per $\mathrm{ml}$ of treatment for AMJ and 1/4-AMJ groups, respectively (Figure 1d).

(a)

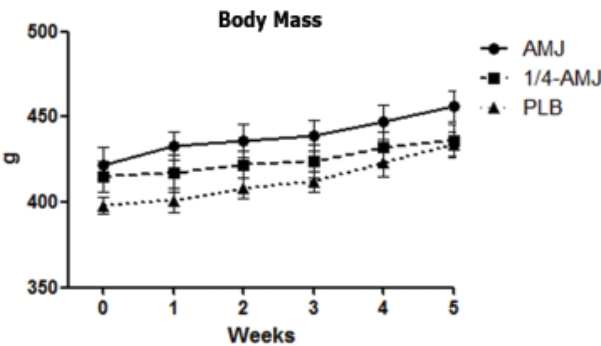

(c)

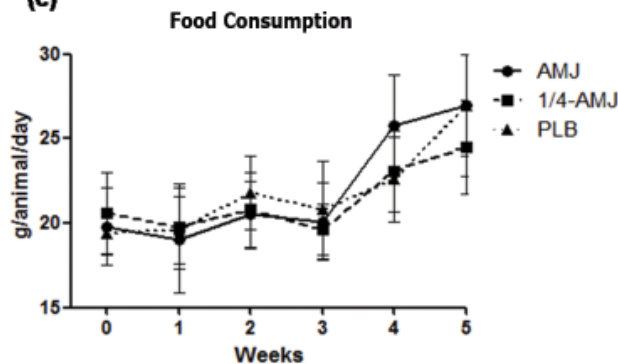

(b)

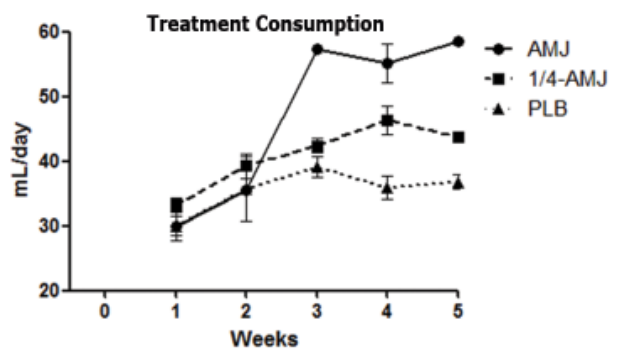

(d) Daily Polyphenol Consumption

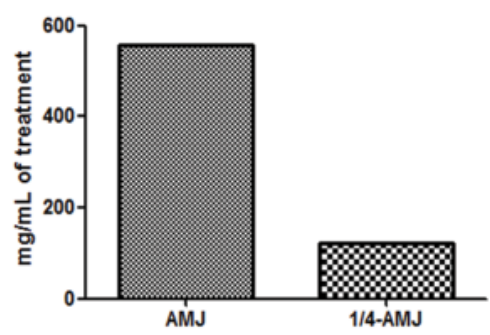

Figure 1. Body mass and daily consumption. (a) changes in body mass; (b) consumption of either of 3 treatments; (c) food consumption; (d) daily polyphenol expenditure. The graphs are represented per3 groups of animals (receiving either AMJ, $1 / 4-A M J$ or PLB) for (a), (b) and (c). The (d) is grouped per animals receiving either AMJ or $1 / 4-A M J$ treatment. All values are plotted as mean $\pm \operatorname{SEM}(a, b, c)$, and daily mean value (d)

\section{Sampling and biochemical analyses}

On day 35 upon treatment, all animals were sacrificed by cardiac puncture under anesthesia, and blood samples were collected for biochemical and laboratory analysis. Blood samples $\left(6-8 \mathrm{~cm}^{3}\right)$ from all rats were collected by aorta abdominalis puncture in Na-citrate containing $(3.8 \% \mathrm{w} / \mathrm{v})$ tubes, and plasma samples were collected upon centrifugation. Liver samples

were stored at $-80^{\circ} \mathrm{C}$. Biochemical parameters were determined from the plasma using standard laboratory kits on Cobas c-111 biochemical analyzer (Roche, Basel, Switzerland).

\section{Preparing liver tissue for phospholipids FA analysis and lipid extraction}

The liver tissue (1 g) was homogenized with a 2:1 chloroform/methanol mixture with butylated hydroxytoluene (BHT) as an antioxidant and washed with 5 times less 
volume of water. The resulting mixture separated into two phases, the lower phase yielding the total pure lipid extract. Further evacuation was done with 2:1 solvent systems: methanol/benzene, acetone/benzene, and ethanol/benzene. Upon adding and evacuation of chloroform and adding hexane afterwards, samples were ready for thin layer chromatography (TLC) [20].

\section{FA analysis in the liver tissue}

The phospholipid fraction was isolated from the extracted lipids by one-dimensional TLC with the neutral lipid solvent system of petrol ether-diethyl ether-acetic acid (87:12:1, v/v) using Silica Gel GF plates (C. Merck, Darmstadt, Germany). The extraction and preparation of FA methyl esters and their gas chromatography analyses were performed as previously described [9]. Briefly, FA methyl-ester derivatives formed from isolated plasma phospholipids fraction were separated by gas chromatography using Shimadzu GC 2014 (Shimadzu Co, Tokyo, Japan) equipped with a flame ionization detector and Rtx 2330 fused silica gel capillary column $(60 \mathrm{~m}$ x $0.25 \mathrm{~mm}$ x $0.2 \mu \mathrm{m}$ ) (Restek Co, Bellefonte, PA, USA). The flame ionization detector was set at $250^{\circ} \mathrm{C}$, the injection port at $220^{\circ} \mathrm{C}$, and the oven temperature programmed from 130 to $190^{\circ} \mathrm{C}$ at heating rate of $3^{\circ} \mathrm{C} / \mathrm{min}$. Comparing sample peak retention times with authentic standards (Sigma Chemical Co, St. Louis, MO, USA) and/or the PUFA-2 standard mixture (Supelco Inc., Belleforte, PA, USA), individual FA methyl esters were identified [21].

\section{Lipid extraction and plasma phospholipids FA analysis}

The total lipid extract was prepared by the method described by Folch [21]. The phospholipid fraction was isolated as indicated. The extraction and preparation of FA methyl esters and their gas chromatography analyses were performed as indicated. The identification of FA methyl esters was made by comparing sample peak retention times with authentic standards (PUFA-2 and/or 37 FAMEs mix, Supelco, Bellefonte, PA, USA) [22]. Finally, individual FA starting from palmitic acid (PA, 16:0) through docosahexaenoic acid (DHA, 22:6 n-3) were expressed as a percent in total identified FA.

\section{Statistical analysis}

The results are presented as mean \pm SD. The differences between the groups were calculated by one-way Analyses of Variance (One-way ANOVA) followed by Tukey's Post Test of individual significant differences between the groups. Analysis was performed using the SPSS software (ver. 15.0; Chicago, IL), and the level of significance was set at $\mathrm{P}<0.05$.

The sample size was calculated according to data on chokeberry effects on plasma cholesterol fractions content previously reported [23]. With statistical power set at $80 \%(\beta=0.80)$ and $\mathrm{P}$ value of 0.05 , the required number of animals was minimum 7 per group. 


\section{RESULTS}

\section{Biochemical parameters}

LDL fraction was decreased in the group receiving AMJ compared to the control group receiving PLB $(\mathrm{P}=0.021)$ (Table 2$)$.

Table 2. Biochemical parameters in control (PLB) and treated animals (1/4-AMJ or AMJ)

\begin{tabular}{lccc}
\hline & $\begin{array}{c}\text { Control } \\
(\mathbf{n}=8)\end{array}$ & $\begin{array}{c}1 / 4-A M J \\
(\mathbf{n}=8)\end{array}$ & $\begin{array}{c}\text { AMJ } \\
(\mathbf{n}=8)\end{array}$ \\
\hline TC $[\mathrm{mmol} / \mathrm{L}]$ & $0.91 \pm 0.09$ & $1.05 \pm 0.10$ & $0.96 \pm 0.17$ \\
\hline Glu $[\mathrm{mmol} / \mathrm{L}]$ & $8.94 \pm 1.35$ & $9.61 \pm 3.62$ & $7.31 \pm 1.27$ \\
\hline HDL $[\mathrm{mmol} / \mathrm{L}]$ & $0.78 \pm 0.08$ & $0.72 \pm 0.09$ & $0.70 \pm 0.10$ \\
\hline LDL $[\mathrm{mmol} / \mathrm{L}]$ & $0.12 \pm 0.03$ & $0.14 \pm 0.04$ & $0.09 \pm 0.03^{* \#}$ \\
\hline TAG $[\mathrm{mmol} / \mathrm{L}]$ & $0.72 \pm 0.14$ & $0.96 \pm 0.16$ & $0.99 \pm 0.44$ \\
\hline
\end{tabular}

Level of significant difference upon ANOVA. *compared to control group; ${ }^{*}$ comparison between groups $\mathrm{P}<0.05$. Data are presented as mean \pm SD. TC-total cholesterol; GLU-glucose; HDL-high-density lipoprotein; LDL-low-density lipoprotein; TAG-triglyceride.

\section{The changes in plasma phospholipids FA composition upon 5-weeks placebo-controlled aronia intervention}

There was a significant, dose-dependent increase in plasma VA content in aroniareceiving animals in comparison with $\mathrm{PLB}$-receiving animals $(\mathrm{P}=0.039, \mathrm{P}=0.003$, for $1 / 4-A M J$ and AMJ, respectively). A statistically significant increase was observed for total plasma MUFA in animals on either AMJ or $1 / 4-A M J$, in comparison with animals on PLB (Table 3), which was more pronounced in the AMJ group (P=0.017), than in $1 / 4-\mathrm{AMJ}(\mathrm{P}=0.042)$.

Table 3. Plasma phospholipid fatty acid content in control (PLB) and treated animals $(1 / 4-A M J$ and $\mathrm{AMJ}$ )

\begin{tabular}{lccc}
\hline & $\begin{array}{c}\text { Control } \\
(\mathbf{n}=\mathbf{8})\end{array}$ & $\begin{array}{c}\text { AMJ } \\
(\mathbf{n}=\mathbf{8})\end{array}$ & $\begin{array}{c}\mathbf{1} / 4-\mathbf{A M J} \\
\mathbf{( n = 8 )}\end{array}$ \\
\hline $16: 0$ & $24.57 \pm 0.76$ & $24.25 \pm 1.45$ & $23.38 \pm 1.49$ \\
\hline $18: 0$ & $22.06 \pm 0.82$ & $21.56 \pm 1.48$ & $21.79 \pm 1.20$ \\
\hline SFA & $46.63 \pm 0.83$ & $45.80 \pm 2.66$ & $45.17 \pm 2.18$ \\
\hline $16: 1$ & $0.43 \pm 0.06$ & $0.46 \pm 0.12$ & $0.41 \pm 0.15$ \\
\hline $18: 1 \mathrm{n}-9$ & $3.95 \pm 0.63$ & $4.47 \pm 0.46$ & $4.55 \pm 0.42$ \\
\hline $18: 1 \mathrm{n}-7$ & $2.66 \pm 0.22$ & $3.34 \pm 0.48^{* *}$ & $3.14 \pm 0.33^{*}$ \\
\hline MUFA & $7.04 \pm 0.74$ & $8.28 \pm 0.93^{*}$ & $8.10 \pm 0.76^{*}$ \\
\hline
\end{tabular}




\begin{tabular}{lccc}
\hline cont. Table 3. & & & \\
\hline $18: 2 \mathrm{n}-6$ & $21.75 \pm 1.38$ & $22.38 \pm 1.65$ & $21.05 \pm 1.76$ \\
$20: 3 \mathrm{n}-6$ & $1.12 \pm 0.24$ & $1.22 \pm 0.25$ & $1.22 \pm 0.28$ \\
\hline $20: 4 \mathrm{n}-6$ & $16.89 \pm 1.60$ & $15.48 \pm 0.98$ & $17.14 \pm 1.52$ \\
\hline $20: 5 \mathrm{n}-3$ & $0.50 \pm 0.08$ & $0.59 \pm 0.11$ & $0.58 \pm 0.16$ \\
\hline $22: 4 \mathrm{n}-6$ & $0.41 \pm 0.06$ & $0.41 \pm 0.17$ & $0.50 \pm 0.11$ \\
\hline $22: 5 \mathrm{n}-3$ & $0.94 \pm 0.25$ & $0.97 \pm 0.22$ & $0.95 \pm 0.27$ \\
\hline $22: 6 \mathrm{n}-3$ & $4.71 \pm 0.72$ & $4.80 \pm 0.93$ & $5.29 \pm 0.36$ \\
PUFA & $46.33 \pm 1.39$ & $45.84 \pm 1.94$ & $46.73 \pm 2.47$ \\
$\mathrm{n}-6$ & $40.18 \pm 1.19$ & $39.49 \pm 1.50$ & $39.90 \pm 2.53$ \\
$\mathrm{n}-3$ & $6.15 \pm 0.83$ & $6.36 \pm 1.14$ & $6.83 \pm 0.47$ \\
$\mathrm{n}-6 / \mathrm{n}-3$ & $6.63 \pm 0.88$ & $6.37 \pm 1.08$ & $5.88 \pm 0.64$ \\
\hline Omega-3-Index & $5.21 \pm 0.75$ & $5.39 \pm 1.03$ & $5.88 \pm 0.40$ \\
\hline AA/EPA & $34.89 \pm 6.96$ & $27.02 \pm 4.25$ & $31.46 \pm 0.45$ \\
\hline
\end{tabular}

Level of significant difference upon ANOVA followed by Tukey's Post Hoc multiple comparison test. $* \mathrm{P}<0.05 ;{ }^{* *} \mathrm{P}<0.01$. Data are presented as $\%$ of fatty acids in the total pool. SFA-total saturated fatty acids; MUFA-total monounsaturated fatty acids; PUFA-polyunsaturated fatty acids; Omega-3-Index$\mathrm{EPA}+\mathrm{DHA}$.

\section{Changes in liver phospholipids FA composition}

The same as for plasma phospholipids, the levels of VA were significantly increased in animals upon aronia juice exposure in a dose-dependent way, especially pronounced in the case of AMJ $(\mathrm{P}=0.001)$, in comparison with levels of VA in control animals. Oleic acid (OA, 18:1n-9) followed the same increasing trend, which consequently led to a significant increase in total MUFA levels in liver phospholipids (Table 4), again in a dose-dependent fashion, AMJ (P = 0.023) versus PLB.

Upon polyphenol treatment there was a dose-dependent decrease in stearic acid (SA, 18:0) in liver phospholipids ( $\mathrm{P}=0.01, \mathrm{P}=0.005$, for $1 / 4-\mathrm{AMJ}$ and $\mathrm{AMJ}$, respectively) compared to PLB treatment (Table 4).

Both aronia treatments increased the percentage of docosapentaenoic acid (DPA, 22:5n-3) ( $\mathrm{P}=0.076, \mathrm{P}=0.049$, for AMJ and $1 / 4-\mathrm{AMJ}$, respectively). Additionally, there was a significant increase in $\mathrm{n}-3$ PUFA $(\mathrm{P}=0.053)$ upon AMJ treatment, compared to PLB treatment (Table 4).

In comparison with the control level, the level of AA, upon 5-week consumption of AMJ was significantly decreased $(\mathrm{P}=0.05)$ in liver phospholipids (Table 4). Also, there was an increase in the percentage of DGLA $(\mathrm{P}=0.05)$ in AMJ group compared to PLB group (Table 4). 
Table 4. Liver phospholipid fatty acid content in control (PLB) and treated animals (1/4-AMJ and AMJ).

\begin{tabular}{lccc}
\hline & $\begin{array}{c}\text { Control } \\
(\mathbf{n}=\mathbf{8})\end{array}$ & $\begin{array}{c}\text { AMJ } \\
(\mathbf{n}=\mathbf{8})\end{array}$ & $\begin{array}{c}1 / 4-\mathbf{A M J} \\
(\mathbf{n}=8)\end{array}$ \\
\hline $16: 0$ & $19.91 \pm 0.57$ & $20.52 \pm 0.91$ & $21.01 \pm 1.21$ \\
\hline $18: 0$ & $22.24 \pm 0.93$ & $20.70 \pm 0.51^{* * *}$ & $20.78 \pm 0.88^{*}$ \\
\hline SFA & $42.15 \pm 0.83$ & $41.22 \pm 0.98$ & $41.79 \pm 1.07$ \\
\hline $16: 1$ & $0.57 \pm 0.12$ & $0.59 \pm 0.15$ & $0.55 \pm 0.11$ \\
\hline $18: 1 \mathrm{n}-9$ & $3.10 \pm 0.50$ & $3.19 \pm 0.29$ & $3.19 \pm 0.34$ \\
\hline $18: 1 \mathrm{n}-7$ & $2.68 \pm 0.25$ & $3.50 \pm 0.48^{* * *}$ & $3.13 \pm 0.31$ \\
\hline MUFA & $6.35 \pm 0.57$ & $7.29 \pm 0.72^{*}$ & $6.87 \pm 0.44$ \\
\hline $18: 2 \mathrm{n}-6$ & $15.99 \pm 1.85$ & $16.33 \pm 0.96$ & $16.59 \pm 1.09$ \\
\hline $20: 3 n-6$ & $0.90 \pm 0.15$ & $1.08 \pm 0.10^{*}$ & $1.01 \pm 0.14$ \\
\hline $20: 4 \mathrm{n}-6$ & $25.65 \pm 1.23$ & $24.08 \pm 1.26^{*}$ & $24.06 \pm 1.02$ \\
\hline $20: 5 \mathrm{n}-3$ & $0.69 \pm 0.18$ & $0.79 \pm 0.14$ & $0.80 \pm 0.15$ \\
\hline $22: 4 \mathrm{n}-6$ & $0.27 \pm 0.02$ & $0.30 \pm 0.03$ & $0.26 \pm 0.03$ \\
\hline $22: 5 \mathrm{n}-3$ & $1.09 \pm 0.14$ & $1.26 \pm 0.14^{*}$ & $1.28 \pm 0.12^{*}$ \\
\hline $22: 6 n-3$ & $7.26 \pm 0.63$ & $7.64 \pm 0.54$ & $7.34 \pm 0.39$ \\
\hline PUFA & $51.84 \pm 0.93$ & $51.48 \pm 1.28$ & $51.35 \pm 0.75$ \\
\hline n-6 & $42.81 \pm 1.33$ & $41.79 \pm 1.54$ & $41.92 \pm 1.08$ \\
\hline n-3 & $9.03 \pm 0.68$ & $9.69 \pm 0.45^{*}$ & $9.43 \pm 0.43$ \\
\hline n-6/n-3 & $4.77 \pm 0.47$ & $4.32 \pm 0.33$ & $4.46 \pm 0.30$ \\
\hline Omega-3-Index & $7.94 \pm 0.65$ & $8.43 \pm 0.44$ & $8.15 \pm 0.36$ \\
\hline AA/EPA & $40.15 \pm 12.68$ & $31.42 \pm 6.93$ & $31.08 \pm 7.60$ \\
\hline
\end{tabular}

Level of significant difference upon ANOVA followed by Tukey's Post Hoc multiple comparison test. $* \mathrm{P}<0.05 ;{ }^{* *} \mathrm{P}<0.01 ; * * * \mathrm{P}<0.001$. Data are presented as $\%$ of fatty acids in the total pool. SFA-total saturated fatty acids; MUFA-total monounsaturated fatty acids; PUFA-polyunsaturated fatty acids; Omega-3-Index-EPA+DHA.

\section{DISCUSSION}

One of the greatest advantages of the study described herein is the application of an intermediate treatment dose. Three different treatments were applied (placebo beverage, and two doses of aronia juice differing in polyphenol content) to three groups of animals, thus enabling the evaluation of a polyphenol dose-dependent effect on the lipid status. Our results indicated the favorable effect of aronia juice consumption regarding lipid classes including LDL and FA phospholipids in the plasma and liver. The novelty of this work is the investigation of a dose-dependent biological effect of polyphenol-rich aronia juice towards endogenous tissue phospholipid FA status in rats. 
AMJ had a favorable decreasing effect on LDL level, while 1/4-AMJ showed the opposite (Table 2). The exactly same trend, but without statistical significance, was observed in Glu level upon treatment with two polyphenol doses of aronia juice in comparison to the control. The hypocholesterolemic effect of aronia polyphenols was previously demonstrated in rats with experimentally induced hyperlipidemia $[1,23,24]$. The hypoglycemic effect of aronia incorporated into drinking water was observed in diabetic and normal rats upon intraperitoneal administration [25].

The postulated protective, lipid-lowering effects of high polyphenol doses in AMJ, might account for the LDL decrease in the sub-cohort of animals receiving AMJ. Qin and Anderson [15] have reported similar results, demonstrating a beneficial metabolic shift in fructose fed rats receiving the aronia extract in comparison with those on the fructose diet solely.

Aronia juice consumption exerted a consistent biological effect on rat plasma and liver phospholipid FA profiles, upon 5-weeks of aronia treatment. Upon treatment with both doses of aronia juice, and in comparison with the control animals receiving PLB, there was an increase in OA, VA, and total MUFA levels, both in the plasma and liver. OA has anti-atherogenic and antithrombotic properties and increases HDL to LDL ratio. Incorporation of $\mathrm{OA}$ into cholesterol esters, triglycerides and phospholipids of lipoprotein particles reduce lipoprotein oxidation. Incorporated into membrane lipids, $\mathrm{OA}$ regulates the fluidity of the cell membrane, the efficiency of transmembrane transport and affects signal transduction [26].

The dose-dependent increase in VA and MUFA levels was statistically significant, which indicates the additive effect of polyphenol content, in both tissues.

Studies dealing with the health implications of cis-VA status are scarce. An interesting finding indicates an unfavorable association of reduced levels of VA in plasma and liver of hypertensive rats with the incidence of stroke-like metabolic features [27]. The inverse association of cis-VA has been demonstrated in human studies investigating the correlation of its content in red blood cells and plasma with the incidence of myocardial infarction and heart failure with antecedent coronary heart disease, respectively $[28,29]$. Accordingly, the current finding indicates the potentially favorable effect of aronia juice through the elevation of cis-VA plasma and liver content.

The decrease in SFA is dose/dependent in liver phospholipids, and may be indicative of AMJ protective effects because long-chain SFA are speculated to induce proinflammatory responses [30] and apoptosis of different vascular cell types [31].

The herein reported decrease in SFA in both tissues additionally indicates aroniaprotective effects, especially since it is coupled with the aronia-induced statistically significant increase in MUFA levels, contemplated to be associated to beneficial inflammatory properties [32].

Also, DGLA that was increased in the liver upon AMJ treatment exert antiinflammatory properties [33]. We have reported a dose-dependent decline in AA level, 
in both tissues, that contributed to the dose-dependent decrease in overall n-6 PUFA. It is well known that AA is further metabolized to potent inflammatory eicosanoids.

Additionally, both in the liver and plasma, there was an increase in EPA, DPA and DHA levels upon both polyphenol aronia doses, followed by a dose-dependent increase in total n-3 PUFA level, Omega-3-Index, as well as decrease in n- $6 / n-3$ ratio. In contrast to n-6 PUFA, n-3 PUFA exert bypolipidemic, vasodilatory, antithrombotic, and anti-inflammatory properties [34].

We demonstrated an increase in Omega-3-Index (EPA + DHA content) and a decrease in AA to EPA ratio upon aronia juice consumption. Since the Omega-3Index is inversely [35], and AA/EPA ratio directly associated with CVD risk [36], the results indicate additional aronia-juice cardio-protective effects.

Available exploratory preclinical research data on AM health effects [11-14] support our findings. Thus, consumption of aronia juice or chokeberry extract incorporated in the standard diet, has shown health-promoting properties in experimental rodent models, including rat models of arterial hypertension [13], hyperlipidemia [1], metabolic syndrome [14], and glucose metabolic disorders which preferentially lead to diabetes [15]. Additionally, the pretreatment with aronia in laboratory rats has shown anti-oxidative effects in the case of diet- [12,37] and chemically [11] induced oxidative stress. Observed beneficial effects are attributed to the bioactivity of polyphenols. We postulated a polyphenol dose-dependent cardio-protective effect in rats, through the balancing of crucial fatty acid classes: increase in MUFA and n-3 PUFA levels, as well as an overall decline in the levels of saturated fats. Possible background of polyphenol bioactivity towards lipid metabolism is discussed in the available literature. In addition to the adipocyte cell cycle disruption, lipido-protective mechanisms for polyphenol dietary intake include several pathways: inhibition of de novo lipogenesis, lipolysis promotion, fatty acid $\beta$-oxidation promotion, as well as different anti-inflammatory mechanisms coupled with balancing of intracellular and intra-tissue oxidative stress and insulin sensitivity improvement [38].

We concluded a dose-dependent beneficial effect of aronia juice consumption on LDL and plasma and liver phospholipids fatty acid profiles in aronia-treated Wistar rats. The implications from the current pre-clinical study in phospholipids FA profiles are to be confirmed in large-scale clinical trials, encompassing both healthy and at-risk, disease-free populations.

\section{Acknowledgments}

This work was supported by the Ministry of Education, Science and Technological Development of the Republic of Serbia, under Grant number III41030. The authors are grateful to "Nutrika" Company, Belgrade, Serbia. 


\section{Authors' contributions}

ZM drafted the manuscript and performed the statistical analysis. DMJ, RS and PB carried out the analysis and interpretation of data as well as revising the manuscript critically for important intellectual content. IĐ carried out the analyisi. GM and TM have made substantial contributions to conception and design. PT carried out the analysis and interpretation of data as well as revising the manuscript critically for important intellectual content and have given final approval of the version to be published. All authors read and approved the final manuscript.

\section{Declaration of conflicting interests}

The author(s) declared no potential conflicts of interest with respect to the research, authorship, and/or publication of this article.

\section{REFERENCES}

1. Valcheva-Kuzmanova S, Kuzmanov K, Mihova V, Krasnaliev I, Borisova P, Belcheva A: Antihyperlipidemic effect of Aronia melanocarpa fruit juice in rats fed a high-cholesterol diet. Plant Food Hum Nutr 2007, 62: 19-24.

2. Kähkönen MP, Hopia AI, Vuorela HJ, Rauha JP, Pihlaja K, Kujala TS, Heinonen M: Antioxidant activity of plant extracts containing phenolic compounds. J Agr Food Chem 1999, 47: 3954-3962.

3. Lampe JW: Health effects of vegetables and fruits: assessing mechanisms of action in human experimental studies. Am J Clin Nutr 1999, 70: 475-490.

4. Paganga G, Miller N, Rice-Evans CA: The polyphenolic content of fruits and vegetables and their antioxidant activities. What does a serving constitute? Free Radical Res 1999, 30: 153-162.

5. Arbuckle LD, MacKinnon MJ, Innis SM: Formula 18:2(n-6) and 18:3(n-3) content and ratio influence long-chain polyunsaturated fatty acids in the developing piglet liver and central nervous system. J Nutr 1994, 124: 289-298.

6. Blank C, Neumann MA, Makrides M, Gibson RA: Optimizing DHA levels in piglets by lowering the linoleic acid to alpha-linolenic acid ratio. J Lipid Res 2002, 43: 1537-1543.

7. Simopoulos AP: Essential fatty acids in health and chronic disease. Am J Clin Nutr 1999, 70: 560-569.

8. Mougios V, Kotzamanidis C, Koutsari C, Atsopardis S: Exercise-induced changes in the concentration of individual fatty acids and triacylglycerols of human plasma. Metabolism 1995, 44: 681-688.

9. Popović T, Ranić M, Bulajić P, Milicević M, Arsić A, Vučić V, Glibetić M: Effects of n-3 fatty acids supplementation on plasma phospholipids fatty acid composition in patients with obstructive jaundice- a Pilot Study. J Clin Biochem Nutr 2009, 45: 370.

10. Brzóska MM, Rogalska J, Galazyn-Sidorczuk M, Jurczuk M, Roszczenko A, Tomczyk M: Protective effect of Aronia melanocarpa polyphenols against cadmium-induced disorders in bone metabolism: A study in a rat model of lifetime human exposure to this heavy metal. Chem-Biol Interact 2015, 229: 132-146. 
11. Kujawska M, Ignatowicz E, Ewertowska M, Oszmiański J, Jodynis-Liebert J: Protective effect of chokeberry on chemical-induced oxidative stress in rat. Hum Exp Toxicol 2011, 30: 199-208.

12. Francik R, Krośniak M, Sanocka I, Bartoń H, Hebda T, Francik S: Aronia melanocarpa treatment and antioxidant status in selected tissues in Wistar rats. BioMed Res Int 2014, doi: 10.1155/2014/457085.

13. Ciocoiu M, Badescu L, Miron A, Badescu M: The involvement of a polyphenol-rich extract of black chokeberry in oxidative stress on experimental arterial hypertension. Evid-Based Compl Alt 2013, doi: 10.1155/2013/912769.

14. Jurgoński A, Juśkiewicz J, Zduńczyk Z: Ingestion of black chokeberry fruit extract leads to intestinal and systemic changes in a rat model of prediabetes and hyperlipidemia. Plant Food Hum Nutr 2008, 63:176-182.

15. Qin B, Anderson RA: An extract of chokeberry attenuates weight gain and modulates insulin, adipogenic and inflammatory signalling pathways in epididymal adipose tissue of rats fed a fructose-rich diet. Brit J Nutr 2012, 108: 581-587.

16. Airanthi MWA, Sasaki N, Iwasaki S, Baba N, Abe M, Hosokawa M, Miyashita K: Effect of brown seaweed lipids on fatty acid composition and lipid hydroperoxide levels of mouse liver. J Agr Food Chem 2011, 59: 4156-4163.

17. Aoun M, Michel F, Fouret G, Schlernitzauer A, Ollendorff V, Wrutniak-Cabello C, Cristol JP, Carbonneau MA, Coudray C, Feillet-Coudray C: A grape polyphenol extract modulates muscle membrane fatty acid composition and lipid metabolism in high-fat-high-sucrose diet-fed rats. Brit J Nutr 2011, 106: 491-501.

18. Wolfe K, Wu X, Liu RH: Antioxidant activity of apple peels. J Agr Food Chem 2003, 51: 609-614.

19. Tomić M, Ignjatovic D, Tovilović-Kovačević G, Krstić-Milosević D, Ranković S, Popović T, Glibetić M: Reduction of anxiety-like and depression-like behaviors in rats after one month of drinking Aronia melanocarpa berry juice. Food Funct 2016, 7(7):3111-3120.

20. Popović T, Borozan S, Arsić A, Debeljak-Martačić J, Vučić V, Trbović A, Mandić L, Glibetić M: Fish oil supplementation improved liver phospholipids fatty acid composition and parameters of oxidative stress in male Wistar rats. J Anim Physio An N 2012, 96: 1020 1029.

21. Folch J, Lees M, Sloane-Stanley GH: A simple method for the isolation and purification of total lipids from animal tissues. J Biol Chem 1957, 226: 497-509.

22. Popović T, Borozan S, Arsić A, Debeljak-Martačić J, Vučić V, de Luka S, Milovanović I, Trbović A, Glibetić M: Effects of n-3 supplementation on plasma and liver phospholipid fatty acids profile in aged Wistar rats. Croat Chem Acta 2011, 84: 73-79.

23. Valcheva-Kuzmanova S, Kuzmanov K, Tancheva S, Belcheva A: Hypoglycemic and hypolipidemic effects of Aronia melanocarpa fruit juice in streptozotocin-induced diabetic rats. Methods Find Exp Clin Pharmacol 2007, 29: 101-105.

24. Valcheva-Kuzmanova S, Kuzmanov K, Tsanova-Savova S, Mihova V, Krasnaliev I, Borisova P: Lipid-lowering effects of Aronia melanocarpa fruit juice in rats fed cholesterol-containing diets. J Food Biochem 2007, 31: 589-602.

25. Maslov DL, Ipatova OM, Abakumova O, Tsvetkova TA, Prozorovskiü VN: Hypoglycemic effect of an extract from Aronia melanocarpa leaves. Vopr Med Khim 2001, 48: 271-277.

26. Mead JF: The metabolism of polyunsaturated fatty acids. In: Progress in the chemistry of fats and other lipids. Oxford, United Kindgom: Pergamon Press 1971, 161-189. 
27. Tanaka S, Kojiguchi C, Yamazaki T, Mitsumoto A, Kobayashi D, Kudo N, Kawashima Y: Altered fatty acid profile in the liver and serum of stroke-prone spontaneously hypertensive rats: reduced proportion of cis-vaccenic acid. J Oleo Sci 2012, 62: 933-948.

28. Djoussé L, Matthan NR, Lichtenstein AH, Gaziano JM: Red blood cell membrane concentration of cis-palmitoleic and cis-vaccenic acids and risk of coronary heart disease. Am J Cardiol 2012, 110: 539-544.

29. Djoussé L, Matsumoto C, Hanson NQ, Weir NL, Tsai MY, Gaziano JM: Plasma cis-vaccenic acid and risk of heart failure with antecedent coronary heart disease in male physicians. Clin Nutr 2014, 33: 478-482.

30. Pradhan AD, Manson JE, Rifai N, Buring JE, Ridker PM: C-reactive protein, interleukin 6, and risk of developing type 2 diabetes mellitus. J Am Med Assoc 2001, 286: 327-334.

31. Jove M, Planavila A, Laguna JC, Vazquez-Carrera M: Palmitate-induced interleukin 6 production is mediated by protein kinase $\mathrm{C}$ and nuclear-factor kappaB activation and leads to glucose transporter 4 down-regulation in skeletal muscle cells. Endocrinology 2005, 146: 3087-3095.

32. Kremmyda LS, Tvrzicka E, Stankova B, Zak A: Fatty acids as biocompounds: Their role in human metabolism, health and disease-a review. Part 2: Fatty acid physiological roles and applications in human health and disease. Biomed Pap 2011, 155: 195-218.

33. Marra CA, de Alaniz MJ, Brenner RR: Effect of various steroids on the biosynthesis of arachidonic acid in isolated hepatocytes and HTC cells. Lipids 1988, 23: 1053-1058.

34. Simopoulos AP: Essential fatty acids in health and chronic diseases. Forum Nutr 2003, 56: $67-70$.

35. Aarsetoey H, Aarsetoey R, Lindner T, Staines H, Harris WS, Nilsen DW: Low levels of the omega-3 index are associated with sudden cardiac arrest and remain stable in survivors in the subacute phase. Lipids 2011, 46: 151-161.

36. Blasbalg TL, Hibbeln JR, Ramsden CE, Majchrzak SF, Rawlings RR: Changes in consumption of omega-3 and omega- 6 fatty acids in the United States during the 20th century. Am J Clin Nutr 2011, 93:950-962.

37. Petrović S, Arsić A, Popović T, Debeljak-Martačić J, Đurendić-Brenesel M, Pilija V, Milić N, Mandić A, Glibetić M: Alternations in fatty acid composition of brain phospholipids in rats supplemented with buckwheat leaf and flower mixture. Acta Vet-Beograd 2015, 65(3), 390-403.

38. Wang S, Moustaid-Moussa N, Chen L, Mo H, Shastri A, Su R, Bapat P, Kwun I, Shen CL: Novel insights of dietary polyphenols and obesity. J Nutr Biochem 2014, 25: 1-18. 


\section{EFEKAT ARONIJE (Aronia melanocarpa) NA MASNOKISELINSKI PROFIL FOSFOLIPIDA PLAZME I JETRE PACOVA WISTAR SOJA}

ZEC Manja, DEBELJAK MARTAČIĆ Jasmina, RANKOVIĆ Slavica, POKIMICA Biljana, TOMIĆ Mirko, IGNJATOVIĆ Đurđica, GLIBETIĆ Maria, POPOVIĆ Tamara

$\mathrm{Na}$ pacovima Wistar soja je uradjena nutritivna placebo-kontrolisana studija sa ciljem da se ispitaju efekti suplementacije sokom od aronije, u trajanju od pet nedelja, na masno-kiselinski profil fosfolipida plazme i jetre, kao i na nivoe glukoze i holesterola u plazmi. Životinje su podeljene u tri grupe od po osam životinja. Životinje su randomizirane tako da budu na jednom od tri tretmana: sok od aronije sa punom dozom polifenola (AMJ), sok od aronije sa četiri puta manjom dozom polifenola (1/4 AMJ) ili placebo (sok bez polifenola) (PLB). Svaka grupa odraslih mužjaka pacova Wistar soja je dobijala tečnost ad libitum. AMJ tretman je uticao na sniženje nivoa lipoproteina niske gustine (LDL, $\mathrm{P}<0,05)$ u odnosu na PLB. AMJ tretman je uticao na povećanje dihomo- $\gamma$-linolenske kiseline (DGLA, 20:3n-6, $\mathrm{P}<0,05)$, kao i na smanjenje nivoa arahidonske kiseline (AA, 20:4n-6, P<0,05) u odnosu na placebo u fosfolipidima jetre. Tretman sokom od aronije sa visokom dozom polifenola je značajno povećao mononezasićene masne kiseline (MUFA), kako u fosfolipidima jetre $(\mathrm{P}<0,05)$, tako i u fosfolipidima plazme $(\mathrm{P}<0,05)$. Obe doze soka od aronije su značajno povećale nivo korisnih n-3 polinezasićenih masnih kiselina (PUFA) u plazmi i jetri. Uočeno je i dozno zavisno značajno povećanje cis-vakcenske kiseline (VA, 18:1n-7, P<0,001) u fosfolipidima plazme i jetre. Naši rezultati ukazuju na korisne efekte soka od aronije na lipidne parametre kod pacova Wistar soja. Ovakvi nalazi sugerišu mogućnost da unos soka od aronije može biti od koristi u strategijama primarne prevencije kardiovaskulanih oboljenja u humanoj populaciji. 